\title{
Growth of NIH 3T3 Fibroblast Cells Exposed to Carbonated Hydroxyapatite with Incorporated Propolis
}

\author{
Puspaneka Wijayanti $^{1}$, Sri Pramestri Lastianny ${ }^{2}$, Suryono $^{2^{*}}$ \\ ${ }^{1}$ Study Programme of Clinical Dentistry, Faculty of Dentistry Universitas Gadjah Mada, Sleman, Daerah Istimewa \\ Yogyakarta, Indonesia \\ ${ }^{2}$ Department of Periodontics, Faculty of Dentistry, Universitas Gadjah Mada, Sleman, Daerah Istimewa Yogyakarta, \\ Indonesia
}

\begin{abstract}
Carbonated hydroxyapatite is frequently used as bone graft material in dentistry. It is highly biocompatible, has osteoconductive properties and functions as a drug delivery system. Propolis is a natural product from bees that has antibacterial and anti-inflammatory effects and is capable of accelerating wound healing. Incorporating propolis into carbonated hydroxyapatite was expected to enhance the wound-healing process and regenerating alveolar bone in the treatment of periodontitis by stimulating fibroblast growth. The aim of this study was to obtain the best concentration of propolis which was incorporated into the carbonated hydroxyapatite bone graft material to increasing the growth of $3 \mathrm{~T} 3$ fibroblast cells. This study used three treatment groups [carbonated hydroxyapatite with various concentrations of incorporated propolis (5\%, 7.5\% and 10\%)] and one control group (carbonated hydroxyapatite with no propolis). An 3-(4,5-dimetilazol-2-il)-2,5-difeniltetrazolium bromida (MTT) assay was carried out to assess cell viability and absorbance readings were performed by using an ELISA reader. The data were analyzed by using one-way ANOVA. The results showed significant differences between all groups and carbonated hydroxyapatite with $10 \%$ incorporated propolis has the highest cell growth level (125.14\%) of all groups, while the control group has the lowest cell growth. In conclusion, adding propolis to carbonated hydroxyapatite could increase the growth of NIH 3T3 fibroblast cells.
\end{abstract}

Keywords: Carbonated hydroxyapatite, Propolis, NIH 3 T3 fibroblast cells, MTT assay

\section{INTRODUCTION}

Periodontitis is one the most common diseases in dentistry. This chronic inflammatory disease is caused by anaerobic bacteria and could lead to the loss of clinical attachment from periodontal ligament and alveolar bone. Periodontal ligament is a connective tissue that covers the tooth root and connects the cementum at the root of the tooth with alveolar bone. In addition to the fibers in the periodontal ligament, there are also fibroblast cells, endothelial cells, among others cementoblasts and osteoclasts (Carranzza, et al., 2012). Disturbance of fibroblast cells decreases collagen synthesis, which is manifest as various diseases, such as periodontal disease (Fives-Taylor, et al., 1996).

Submitted: November 21, 2019

Revised: March 27, 2020

Accepted: April 15, 2020

*Corresponding author: suryonodent@mail.ugm.ac.id 
Alveolar bone loss is one of the outcomes of periodontitis. Bone grafting is a remodeling therapy that can be used to treat alveolar bone loss. Carbonated hydroxyapatite is a biocompatible alloplastic graft or synthetic bone graft and is used for the management of localized bone loss (Sukumar and Drizhal, 2008) that has osteoconductive property and can also function as drug delivery systems (Ding, et al., 2012). The chemical formula of carbonated hydroxyapatite is $\mathrm{Ca}_{10}\left(\mathrm{PO}_{4} \mathrm{CO}_{3}\right)_{6}(\mathrm{OH})_{2}$. The -OH groups in hydroxyapatite can act as active sites to adsorb bioactive molecules by hydrogen bonds, and thus improve the drug loading and release properties (Guo, et al., 2012).

Wound healing is a complex and ongoing physiological process. Tissue repair begins after the injury in 3 phases: inflammation, proliferation, and remodeling, involving various cells such as keratinocytes, fibroblasts, and endothelial cells. The most important cells among these are fibroblasts, responsible for initiating angiogenesis, epithelialization and collagen formation (Jacob, et al., 2015).

There has been increased interest in recent evidence-based complementary and alternative medicine research using natural products for wound healing (Jacob, et al., 2015). Propolis is a natural resin produced by bees from plant exudate and tree buds and mixed with bees wax and enzymes. Propolis has several therapeutic effects, such as anti-inflammatory, immunomodulatory, antioxidant, antibacterial (Aral, et al., 2015), and osteoinduction (Abdellatif, et al., 2014). Propolis contains flavonoids that work to stimulate the production of growth factors and works by increasing the production of growth factors, in particular, transforming growth factor $\beta$ (TGF- $\beta$ ) and vascular endothelial growth factor, which stimulate fibroblast proliferation and blood vessel formation (Suryono, et al., 2017).

\section{MATERIALS AND METHODS}

\section{Preparation of Carbonated Hydroxyapatite}

Carbonated hydroxyapatite (Gama-Cha $\left.{ }^{\circledR}\right)$ used in this study was manufactured by PT. Swayasa
Prakarsa, Yogyakarta, Indonesia. This carbonated hydroxyapatite is cylindrical with a length of 10 $\mathrm{mm}$, a diameter of $6 \mathrm{~mm}$, and a weight of $70 \mathrm{mg}$. The samples were cut and weighed to $10 \mathrm{mg}$ each. Preparation of Propolis Solution.

Propolis was diluted by double distilled water gradually to obtain concentrations of $10 \%$, $7.5 \%$, and $5 \%$. The propolis used in this study was Propolis Brazilian ${ }^{\circledR}$ produced in Minas Gerais and distributed by Nusa Mega.

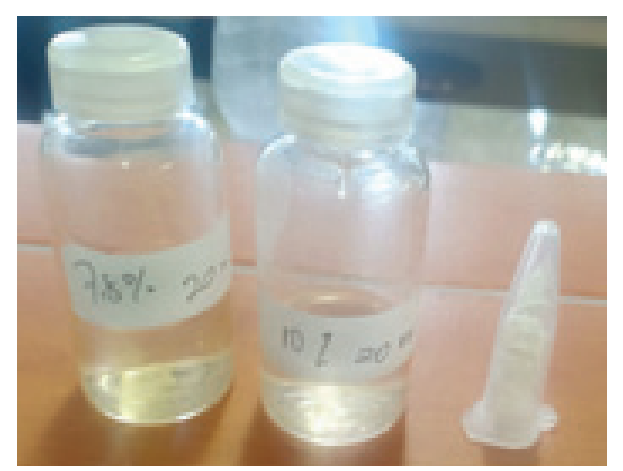

Figure 1. Propolis solution and slice of carbonated hydroxyapatite.

\section{Preparation of Carbonated Hydroxyapatite with Incorporated Propolis}

The carbonated hydroxyapatite were cut and weighed to $10 \mathrm{mg}$ each and propolis was diluted by double distilled water to get various concentrations at $5 \%, 7.5 \%$, and $10 \%$. Carbonated hydroxyapatite was embedded in $1.5 \mathrm{~mL}$ propolis at various concentrations for $24 \mathrm{~h}$ at room temperature. After embedding, the propolis solution was separated from carbonated hydroxyapatite by using a micropipette. The incorporated samples were then covered with filter paper and placed in an incubator at $37^{\circ} \mathrm{C}$ for $24 \mathrm{~h}$ to dry out and then the samples were sterilized by using ethylene oxide (Grenho, et al., 2005).

\section{Cell Culture Preparation}

Fibroblast cells were acquired from the Parasitology Laboratory, Faculty of Medicine, Public Health, and Nursing (FKKMK), Universitas Gadjah Mada. To access the material cytocompati- 
bility, carbonated hydroxyapatite impregnated with $5 \%, 7.5 \%$, and $10 \%$ propolis was selected as the test material. Non-treated carbonated hydroxyapatite was used as a control. In this study fibroblast cell line was used from ATCC with the number NIH3T3. The cell lines were seeded on material samples at a density of $1 \times 10^{4}$ cells $/ \mathrm{mL}$ in Dulbecco's modified Eagle's medium (DMEM) (Sigma-Aldrich, St. Louis, Missouri, USA) supplemented with 10\% Fetal bovine serum (FBS) (Sigma-Aldrich), $100 \mathrm{IU} / \mathrm{mL}$ penicillin (Sigma-Aldrich), $100 \mu \mathrm{g} /$ $\mathrm{mL}$ streptomycin (Sigma-Aldrich) and $2.5 \mu \mathrm{g} / \mathrm{mL}$ fungizone (Sigma-Aldrich). Cell cultures were incubated at $37^{\circ} \mathrm{C}$ in a humidified atmosphere of $5 \%$ $\mathrm{CO}_{2}$. After $24 \mathrm{~h}$ of incubation, cell viability was evaluated through the 3-(4,5-dimetilazol-2-il)-2,5difeniltetrazolium bromida (MTT) reduction assay.

Treatments were administered to 4 groups as follows: group 1, carbonated hydroxyapatite and 5\% propolis (CHA+Prop.5\%); group 2, carbonated hydroxyapatite and $7.5 \%$ propolis (CHA+Prop. $7.5 \%$ ); group 3 , carbonated hydroxyapatite and $10 \%$ propo- lis (CHA+Prop.10\%); and carbonated hydroxyapatite unembedded with propolis as the control group.

Cells were cultured in 96-well microplates as treatment subjects. Three of the wells were used as cell controls. Those wells were only filled with fibroblast cells in DMEM without any treatment. Another three wells were used as media controls, with no fibroblast cells or treatment.

The MTT assay was carried out by adding $100 \mu \mathrm{L}$ MTT solution at a concentration of $0.5 \mathrm{mg} /$ $\mathrm{mL}$ on the cultured cells. Sodium dodecyl sulfate solution $10 \%$ in 0.01 NHCL was added as the stop solution after $4 \mathrm{~h}$. During $4 \mathrm{~h}$, cells were incubated in $5 \% \mathrm{CO}_{2}$ and $37^{\circ} \mathrm{C}$. Absorbance readings were taken using an ELISA reader at a wavelength of $595 \mathrm{~nm}$. The viable cell level was obtained by using the following formula (Shokrzadeh and Modanloo, 2017):

\section{((Treatment absorbance-Media Control Absor-} bance $)$ ) / ((Cell control absorbance-Media Control Absorbance)) $\times 100 \%$
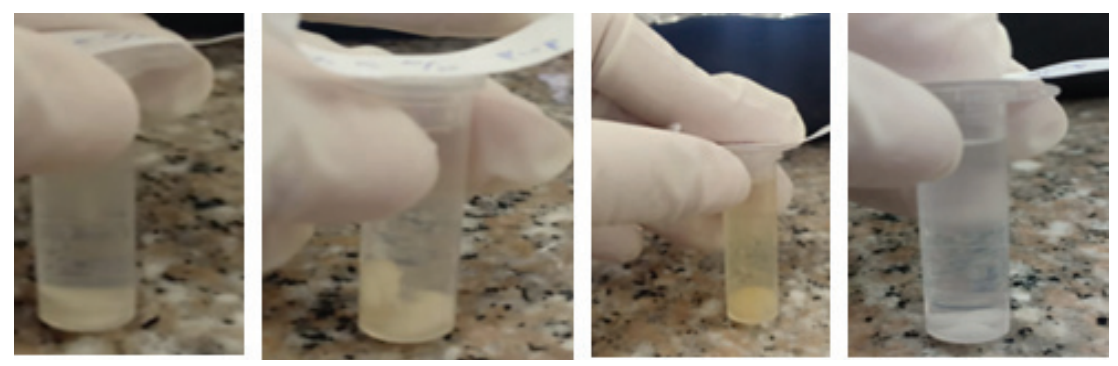

Figure 2. Carbonated hydroxyapatite was embedded in $1.5 \mathrm{~mL}$ propolis. From left $5 \%$ propolis, $7.5 \%$ propolis, $10 \%$ propolis and control.

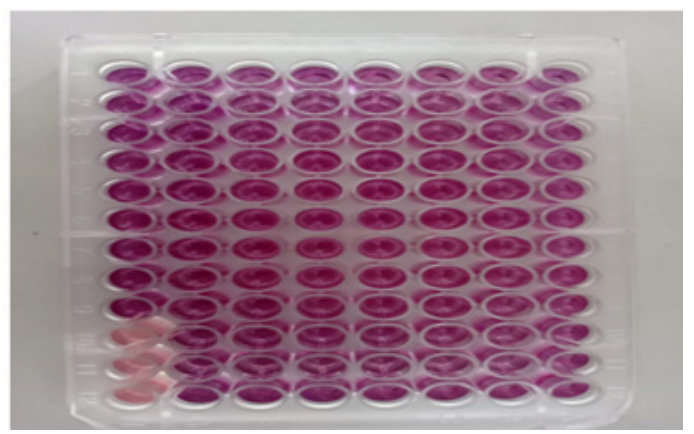

Figure 3. Cells were cultured in 96-well microplates as treatment subjects. 


\section{Statistical analyses}

The percentage of viable cell level were analyzed by using parametric one-way ANOVA at the $95 \%$ level of significance, followed by the least significant difference (LSD) post hoc test.

\section{RESULTS}

The Kolmogorov-Smirnov normality test showed that the data were normally distributed with $p>0.05$. One-way ANOVA revealed a significant difference of variance between tested groups $(p<0.05)$. The data analysis then continued with the LSD post hoc test. Figure 1 shows that the mean percent cell viability of group 1 was the smallest of all 3 groups, namely $98.54 \%$, while group 3 showed the highest cell viability, and group 1 was the lowest. The control group without the addition of propolis showed $96.57 \%$ cell viability.

\section{DISCUSSION}

Carbonated hydroxyapatite is the result of substitution of carbonate ions with a phosphate group from hydroxyapatite. Calcium phosphate composite materials are needed to repair or re- place damaged bones. Carbonated hydroxyapatite has high biocompatibility, bioactivity, and osteoconductive characteristics (Surbakti, et al., 2017). Osteoconduction is a physical effect by which the matrix of the graft forms a scaffold on which cells in the recipient site are able to form new bone (Sukumar and Drizhal, 2008).

Propolis contains active ingredients such as flavonoids and caffeic acid phenethyl ester (CAPE) (Darmadi and Mustamsir, 2016). Flavonoids are capable of regulating cell function by stimulating the production of TGF- $\beta$, which may increase chemotaxis and proliferation of fibroblasts in the wound area. The more fibroblasts at the injured area, the synthesis of collagen immediately started so as to accelerate the wound-healing process (Suryono, et al., 2017). Propolis also contains iron and zinc, which are important in collagen synthesis (Marcucci, 1995).

The results of this study showed that the incorporation of propolis to carbonated hydroxyapatite increased fibroblast growth. These results are in accordance with research conducted by Silva, et al. (2017), which found that propolis had several advantageous effects, such as antibacterial, anti-inflammatory, immunomodulatory and antioxidant.

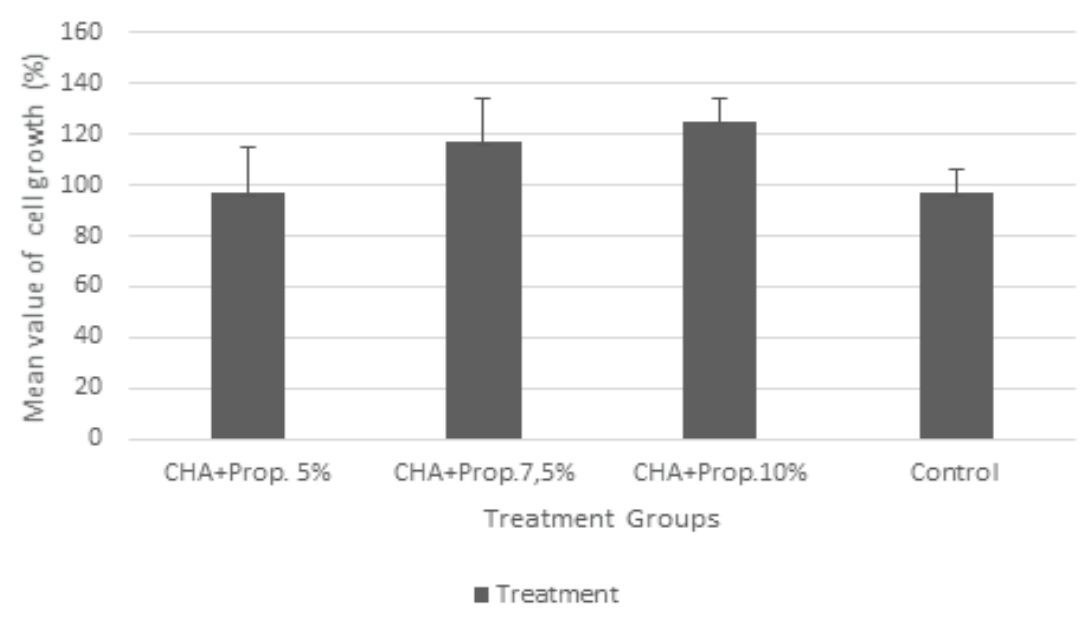

Figure 4. Mean values of cell growth in all groups. 
Post hoc analysis found that the concentration of propolis into carbonated hydroxyapatite determines the growth rate of fibroblast cells, and a propolis concentration of $10 \%$ gives the highest growth rate. These results are in accordance with previous studies by Suryono, et al. (2017), which demonstrated that $10 \%$ propolis can reduce the number of polymorphonuclear cells, stimulate fibroblast growth, and form new vascular tissue. Moreover, Özan, et al. (2007) showed that $10 \%$ propolis was more effective at maintaining periodontal fibroblasts compared with Hank's balanced salt solution and milk for up to $24 \mathrm{~h}$. According to the research of Abdellatif, et al. (2014) propolis used as an orthotopic autograph coating material has a role as osteoinductive and that role cannot be achieved perfectly without the strength of osteoconductive autograph material.

Fibroblasts are one of the most abundant cell types in connective tissues. These cells are responsible for tissue homeostasis under normal physiological conditions. When tissues are injured, fibroblasts become activated and differentiate into myofibroblasts, which generate large contractions and actively produce extracellular matrix (ECM) proteins to facilitate wound closure ( $\mathrm{Li}$ and Wang, 2011).

In this study, $10 \mathrm{mg}$ of carbonated hydroxyapatite was embedded in various concentrations of propolis solution for $24 \mathrm{~h}$. Carbonated hydroxyapatite is a highly biocompatible material that has osteoconductive properties and acts as a drug delivery system. Incorporating propolis into this bone graft material was expected to enhance its capacity for tissue repair (Mai, et al., 2008). Grenho, et al. (2015) reported that embedding nanohydroxyapatite in propolis solution for $24 \mathrm{~h}$ did not show any toxic effects toward fibroblast cells. The cell growth test carried out in this study proved that carbonated hydroxyapatite with incorporated propolis was not toxic, and could even stimulate the growth of fibroblast cells significantly.

\section{CONCLUSION}

The best concentration of propolis incorporated with carbonated hydroxyapatite which could stimulate proliferation of fibroblast cells line was found in $10 \%$.

\section{ACKNOWLEDGMENT}

This study was supported by grant Hibah Penelitian Dana Masyarakat Berbasis Luaran (Outcome Based) Faculty of Dentistry, Universitas Gadjah Mada, Republic of Indonesia, in the fiscal year 2019 under contract No. 4349/UN1/FKG1/Set. $\mathrm{KG} 1 / \mathrm{PT} / 2019$.

\section{REFERENCES}

Abdellatif, B., Mohamed, H., Karim, A. and Asma, B., 2014, Radiography Monitoring of Osteoconduction and Osteoinduction of Orthotopic Allograf Autoclaved Covered Propolis, International Journal of Advances in Life Science and Technology, 1(1), 25-31.

Al-waili, N., 2018, Mixing two different propolis samples potentiates their antimicrobial activity and wound healing property: A novel approach in wound healing and infection, Veterinary World, 11(8), 1188-1195.

Aral, C.A., Kesim, S., Greenwell, H., Kara.M., Cetin, A. and Yakan, B., 2015, Alveolar Bone Protective and Hypoglycemic Effects of Systemic Propolis Treatment in Experimental Periodontitis and Diabetes Mellitus, J Med Food, 18(2), 195-201.

Carranzza, F.A., Newman, M.G., Takei, H.H. and Klokkevosts inid, P.R., 2012, Carranza's Clinical Periodontologi, 11 th ed. St. Louis Missouri:Sounders Elsevier.

Ding, T., Xue, T., Lu,H., Huang, Z. and Sun, J., 2012, Effect of particle size of hydroxyapatite nano particles on its biocompatibility, IEEE Transactions on Nano Bioscience (11) 4. 
Darmadi, D. and Mustamsir, E., 2016, The effect of Propolis on Increasing the Number of Osteoblasts and Chondrocytes, and Decreasing the Number of Osteoclasts in Wistar Rats (Rattusnovergicus) wirth Femoral Bone Fracture, Journal of Dental and Medical Sciences, 15(12), 90-95.

Fives-Taylor, P.M., Meyer, D. and Mintz, K., 1996, Virulence factors of the periodontopathogen Actinobacillus actinomycetemcomitans, J. Periodontol., 67, 291-297.

Guo, Y., Yao, Y., Guo, Y. and Ning, C., 2012, Hydrothermal fabrication of mesoporous carbonated hydroxyapatite microsshperes for a drug delivery system, Microporous and Mesoporous Materials; Elsevier Inc, 155, 245-251

Grenho, L., Barros, J., Ferreira, C., Santos V.R., Monteiro, F.J., Ferraz, M.P. and Cortes, M.E., 2015, In Vitro Antimicrobial Activity and Biocompatibility of Propolis Containing Nanohydroxyapatite, Biomed.Mater, 10.

Jacob, A., Parolia, A., Pau, A. and Amalraj, F.D., 2015, The effects of Malaysian propolis and Brazilian red propolis on connective tissue fibroblasts in the wound healing process, BMC Complementary and Alternative Medicine, 15, 294.

Li, B. and Wang, J., 2009, Fibroblasts and Myofibroblasts in Wound Healing: Force Generation and Measurement, J Tissue Viability, 20(4), 108-120.

Mai, R., Reinstorf, A., Pilling, E., Hlawitschka, M., Jung, R., Gelinsky, M., Schneider, M., Loukota, R., Pompe, W., Eckelt, U. and Stadlinger, B., 2008, Histologic study of incorporation and re- sorption of a bone cement-collagen composite: an in vivo study in the minipig, Oral Surg Oral Med Oral Pathol Oral Radiol Endod, 105, e9. e14.

Marcucci, M.C.,1995, Propolis: chemical composition, biological properties and therapeutic activity, Apidologie, 26, 83-99.

Ozan, F., Polat, Z., A., Er, K., Ozan, U. and Deger, O., 2007, Effect of propolis on survival of periodontal ligament cells: new storage media for avulsed teeth, J.Endod, 33, 570-573.

Shokrzadeh, M. and Modanloo, M., 2017, An overview of the most common methods for assessing cell viability, J.Res.Med.Dent.Sci., 5(2), 33-41.

Silva, R.P., Machado, B.A.S., Barreto, G.D.S., Costa, S.S., Andrade, L.N. and Amaral, R.G., 2017, Antioxidant, antimicrobial, antiparasitic, and cytotoxic properties of various Brazilian propolis extracts. PLoS ONE, 12(3).

Sukumar, S. and Drizhal, I., 2008, Review Article: Bone Grafts in Periodontal Therapy, Acta Medica (Hradec Kralove), 51(4), 203-207.

Surbakti, A., Oley, M.C. and Prasetyo, E., 2017, Perbandingan antara penggunaan karbonat apatit dan hidroksi apatit pada proses penutupan defek kalvaria dengan menggunakan plasma kaya trombosit, Jurnal Biomedik (JBM), 9(2), 107-114.

Suryono, Hasmy, N.S., Pertiwi, T.L., Benyamin, B. and Ismail, A., 2017, Propolis 10\%-Gel as a Topical Drug Candidate on Gingivitis, International Journal of Medicine and Pharmacy, 5(1), 12-17. 